\title{
Arahan Pengembangan Perkebunan Teh (Camellia Sinensis $(L)$.$O .$ Kuntze) Rakyat di Kabupaten Tasikmalaya
}

\author{
Development Direction of Smallholder Tea (Camellia sinensis (L.) O. Kuntze) Plantation \\ in Tasikmalaya Regency
}

\author{
Agung Lukman ${ }^{1 *}$, Atang Sutandi ${ }^{2} \&$ Khursatul Munibah ${ }^{2}$ \\ ${ }^{1}$ Program Studi Ilmu Perencanaan Wilayah, Sekolah Pascasarjana Institut Pertanian Bogor, Kampus IPB \\ Dramaga Bogor 16680, ${ }^{2}$ Departemen Ilmu Tanah dan Sumber daya Lahan, Fakultas Pertanian Institut \\ Pertanian Bogor, Jl. Meranti Kampus IPB Dramaga Bogor 16680; \\ "Penulis korespondensi. e-mail: abifka2010@gmail.com \\ (Diterima: 30 Maret 2017; Disetujui: 19 Juni 2017)
}

\begin{abstract}
Tea is a common plantation commodity cultivated by the community and developed by Tasikmalaya government.According to Tasikmalaya regency regional planning, tea has been established as one of commodities at but it doesn't have further policy dvelopment. The aims of this study are (1) to identify smallholdertea plantation; (2) to analyze land suitability and to identify potential development areas for tea crop; (3) to analyze the feasibility of tea farming; (4) to determine policy development of smallholdertea plantation. Satellite image interpretation was used toidentify smallholdertea plantation. A method of matching criteria was used to analyze land suitability for tea crop and the potential development areas weredetermined by using descriptive analytic. SWOT analysis was used to determine the policy development of smallholdertea plantation. The results showed that tea smallholder plantation was about 6,956hectares. The suitable land for tea crop was about 55,310 hectares and its potential development area was about 14,979 hectares. Smallholdertea plantations was feasible to be developed with $R / C$ ratio 1.73 . In order to support the development of smallholdertea plantation some recommendations aresuggested consisting of (1) the government should encourage the development of tea processing industry to increase farmers income; 2) smallholdertea plantation should be extended considering land availability and suitability; 3) the role of tea smallholder farmer groups and privates plantation should be enhanced to develop tea plantation as a strategic commodity in Tasikmalaya Regency.
\end{abstract}

Keyword: commodity, feasibility of tea farming, land suitability, spatial analysis

\begin{abstract}
ABSTRAK
Teh merupakan komoditas perkebunan yang banyak dibudidayakan oleh masyarakat dan dikembangkan oleh pemerintah Kabupaten Tasikmalaya. Pengembangan teh rakyat tercantum dalam rencana tata ruang wilayah, namun arahannya masih belum jelas.Tujuan penelitian ini adalah (1) mengidentifikasi sebaran lokasi perkebunan teh rakyat; (2) mengevaluasi kesesuaian lahan untuk teh dan mengidentifikasi potensi wilayah pengembangannya; (3) menganalisis kelayakan usaha tani teh rakyat; (4) menyusun arahan pengembangan perkebunan teh rakyat di Kabupaten Tasikmalaya. Metode yang digunakan untuk mengidentifikasi lokasi perkebunan teh rakyat adalah interpretasi citra. Evaluasi kesesuaian lahan menggunakan metode matching criteria yaitu mencocokkan antara persyaratan tumbuh tanaman teh dan karakteristik lahan. Sedangkan potensi wilayah pengembangan di analisis secara deskriptif. Analisis kelayakan usaha tani teh menggunakan pendekatan biaya, penerimaan dan pendapatan usaha tani. Penyusunan arahan pengembangan perkebunan teh rakyat menggunakan metode SWOT. Hasil identifikasi menunjukkan bahwa perkebunan teh rakyat di
\end{abstract}


Kabupaten Tasikmalaya seluas 6,956 ha. Lahan yang sesuai untuk tanaman teh seluas 55,310 ha dengan potensi pengembangan seluas 14,979 ha. Perkebunan teh rakyat layak untuk diusahakan dengan nilai R/C ratio 1.73. Arahan pengembangan perkebunan teh rakyat di Kabupaten Tasikmalaya yang dapat dirumuskan yaitu: (1) pemerintah memfasilitasi upaya peningkatan keuntungan usaha tanidan pembangunan industri pengolahan; (2) peningkatan luas areal perkebunan teh rakyat melalui pengembangan potensi wilayah yang sesuai untuk teh berdasarkan skala prioritas; 3) peningkatan peran kelompok tani teh danperkebunan swasta dalam pengembangan kawasan perkebunan teh.

Kata kunci: analisis spasial, kelayakan usaha tani teh, kesesuaian lahan, komoditas, potensi wilayah

\section{PENDAHULUAN}

Provinsi Jawa Barat merupakan wilayah yang memiliki luas perkebunan terbesar di Indonesia. Pada tahun 2014, luas perkebunan teh di Jawa Barat mencapai 89,977 ha atau $75.68 \%$ dengan jumlah produksi teh mencapai 105,279 ton daun kering. Berdasarkan status pengusahaannya, perkebunan teh di Jawa Barat terdiri atas Perkebunan Rakyat (PR) seluas 45,850 ha; perkebunan besar negara (PBN) seluas 23,213 ha dan perkebunan besar swasta (PBS) seluas 20,914 ha (Pusdatin, 2015).

Salah satu kabupaten di Jawa Barat yang cukup besar memproduksi teh yaitu Kabupaten Tasikmalaya. Pada tahun 2015, luas perkebunan teh rakyat di Kabupaten Tasikmalaya yaitu sebesar 9,039 ha dengan jumlah produksi teh sebanyak 13,238 ton (Dishutbun, 2015). Pemerintah Kabupaten Tasikmalaya telah menetapkan teh sebagai salah satu komoditas perkebunan yang dikembangkan dalam Rencana Tata Ruang Wilayah (RTRW) Tahun 2011 sampai dengan 2031.

Namun rencana pengembangan komoditas ini masih belum jelas. Sebaran perkebunan teh rakyat secara spasial dan kesesuaian lahan untuk tanaman teh masih belum tersedia. Data perkebunan yang tersedia hanya dalam bentuk angka (tabular). Kesesuaian lahan yang tersedia masih bersifat umum untuk pertanian lahan basah, pertanian lahan kering, tanaman tahunan dan tanaman semusim (Bappeda, 2011). Potensi wilayah pengembangan perkebunan teh rakyat belum teridentifikasi dan informasi kelayakan usaha tani perkebunan teh masih belum tersedia.
Berdasarkan kondisi dan permasalahan yang ada, maka diperlukan suatu penelitian untuk menyusun arahan pengembangan perkebunan teh rakyat di Kabupaten Tasikmalaya. Adapun tujuan dari penelitian ini adalah :

1. mengidentifikasi sebaran lokasi perkebunan teh rakyat

2. mengevaluasi kesesuaian lahan untuk tanaman teh dan mengidentifikasi wilayah pengembangannya

3. menganalisis kelayakan usaha tani teh rakyat

4. menyusun arahan pengembangan perkebunan teh rakyat di Kabupaten Tasikmalaya

\section{METODE}

Penelitian dilaksanakan di Kabupaten Tasikmalaya dan Laboratorium Kesuburan Tanah Departemen Ilmu Tanah dan Sumber daya Lahan Fakultas Pertanian IPB selama 9 bulan terhitung mulai dari bulan Juni 2016 sampai dengan bulan Februari 2017. Data yang digunakan dalam penelitian terdiri atas data primer dan sekunder. Pengumpulan data primer dilakukan guna melengkapi data sekunder yang tersedia. Data primer diperoleh darihasil analisis tanah dan wawancara responden sedangkan data sekunder berupa Citra SPOT 6 Tahun 2015, Citra Ikonos 2009, Citra SRTM, peta administrasi, peta penggunaan lahan, peta kawasan hutan, peta HGU perkebunan, peta tanah, peta curah hujan dan peta lereng serta kriteria kesesuaian lahan untuk tanaman teh.

Identifikasi sebaran lokasi perkebunan teh rakyat di Kabupaten Tasikmalaya dilakukan 
melalui dua tahap yaitu: (1) penelusuran data dan studi pustaka; dilanjutkan dengan; (2) interpretasi citra secara visual (Wellala et al., 2012) menggunakan kunci interpretasi (Lillesand dan Kiefer, 1997). Data hasil penelusuran dan studi pustaka selanjutnya digunakan sebagai bahan rujukan dalam interpretasi citra. Lokasi perkebunan teh rakyat deliniasi menggunakan metode digitasi on screen sehingga menghasilkan poligon-poligon peta. Proses deliniasi mempertimbangkan peta penggunaan lahan, peta kawasan hutan dan peta HGU (Hak Guna Usaha) perkebunan yang ada. Poligon-poligon peta sebaran lokasi perkebunan teh yang dihasilkan kemudian dilakukan uji akurasi menggunakan bantuan software google earth, survei lapangan dan wawancara pada tiap kecamatan yang teridentifikasi memiliki perkebunan teh rakyat.

Evaluasi kesesuaian lahan untuk tanaman teh dilakukan dengan cara mencocokkan kriteria kesesuaian persyaratan tumbuh tanaman teh dengan karakteristik lahan (Hardjowigeno dan Widiatmaka, 2007; Ritung et al., 2011) melalui teknik tumpang susun peta (overlay) (Sukmono, 2015). Kriteria kesesuaian lahan yang digunakan dalam evaluasi disajikan pada Tabel 1.

Tabel 1. Kriteria kesesuaian lahan untuk tanaman teh

\begin{tabular}{|c|c|c|c|c|c|}
\hline \multirow{2}{*}{$\begin{array}{l}\text { Kualitas/Karakteristik } \\
\text { lahan }\end{array}$} & \multicolumn{5}{|c|}{ Kelas Kesesuaian Lahan } \\
\hline & Simbol & S1 & S2 & S3 & $\mathbf{N}$ \\
\hline \multirow[t]{2}{*}{ 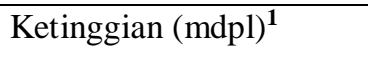 } & (h) & $900-$ & $>1,200-1,500$ & $>1,500-2,000$ & $>2,000$ \\
\hline & & 1,200 & $600-<900$ & $400-<600^{\mathbf{a}}$ & $<400^{\mathbf{a}}$ \\
\hline Ketersediaan Air ${ }^{2}$ & (w) & $2,500-$ & $>4,000-5,000$ & $>5,000-6,000$ & $>6,000$ \\
\hline Curah hujan/tahun (mm) & & 4,000 & $1,800-<2,500$ & $13,00-<1,800$ & $<1,300$ \\
\hline \multicolumn{6}{|c|}{ Media Perakaran } \\
\hline Drainase $\operatorname{tanah}^{\mathbf{3}}$ & & Baik & $\begin{array}{l}\text { Sedang, Agak } \\
\text { cepat }\end{array}$ & Agak terhambat & $\begin{array}{l}\text { Terhambat, } \\
\text { Sangat }\end{array}$ \\
\hline Tekstur $^{2}$ & & $\begin{array}{l}\text { Halus, } \\
\text { agak } \\
\text { halus }\end{array}$ & sedang & Agak kasar & $\begin{array}{l}\text { terhambat, } \\
\text { sangat cepat } \\
\text { Kasar, sangat } \\
\text { halus }\end{array}$ \\
\hline Kedalaman efektif $(\mathrm{cm})^{2}$ & & $>100$ & $75-100$ & $50-<75$ & $<50$ \\
\hline \multicolumn{6}{|l|}{ Retensi hara } \\
\hline KTK Tanah $(\mathrm{cmol})^{2}$ & & $>16$ & $5-16$ & $<5$ & - \\
\hline Kejenuhan basa $(\%)^{2}$ & & $<20$ & $20-35$ & $>35$ & - \\
\hline \multirow[t]{2}{*}{$\mathrm{pH} \mathrm{H} \mathrm{H}_{2} \mathrm{O}^{2)}$} & & $4.5-5.5$ & $3.8-<4.5$ & $<3.8$ & - \\
\hline & & & $>5.5-5.8$ & $>5.8$ & - \\
\hline C-organik $(\%)^{2}$ & & $>0.8$ & $\leq 0.8$ & - & - \\
\hline \multicolumn{6}{|l|}{ Hara tersedia } \\
\hline Total $\mathrm{N}^{3}$ & & $\geq$ Sedang & Rendah & Sangat rendah & - \\
\hline $\mathrm{P}_{2} \mathrm{O}_{5}$ tersedia $^{3}$ & & $\geq$ Sedang & Rendah & Sangat rendah & - \\
\hline $\mathrm{K}_{2} \mathrm{O}$ dapat ditukar ${ }^{3}$ & & $\geq$ Sedang & Rendah & Sangat rendah & - \\
\hline Tingkat bahaya erosi ${ }^{2}$ & (e) & & & & \\
\hline Lereng (\%) & & $<8$ & $8-15$ & $>15-40$ & $>40$ \\
\hline
\end{tabular}

Sumber:

1. Kriteria Puslit Tanah dan Agroklimat (2003) dalam Sukmono (2015)

2. Kriteria Ritung et al. (2011) / BBSDLP

3. Kriteria Hardjowigeno dan Widiatmaka (2007)

a. Penetapan kriteria dengan pertimbangan teknis budi daya teh (Effendi et al. 2010) dan Permentan Nomor 50 Tahun 2014 tentang pedoman teknis budi daya teh yang baik

Evaluasi kesesuaian lahan diawali dengan analisis ketersediaan lahan denganmempertimbangkan kawasan hutan, (HGU) perkebunan, jenis penggunaan lahan dan pola ruang RTRW Kabupaten Tasikmalaya.
Kawasan hutan dan HGU perkebunan merupakan lahan yang tidak tersedia. Penggunaan lahan berupa hutan, kebun, ladang/tegalan semak belukar dan pola ruang untuk lahan kering serta perkebunan dijadikan 
sebagai lahan yang tersedia untuk pengembangan perkebunan teh di Kabupaten Tasikmalaya. Hasil analisis ketersediaan lahan digunakan sebagai bahan analisis kesesuaian lahan.

Karakteristik lahan untuk ketinggian dibuat berdasarkan data kontur sedangkan lereng dibuat berdasarkan data DEM (Digital Elevation Model) dari Citra SRTM (Shuttle Radar Topography Mission) menggunakan analisis slope. Karakteristik ketersediaan air diperoleh dari data curah hujan yang berasal dari Bappeda Kabupaten Tasikmalaya.

Karakteristik lahan untuk media perakaran, retensi hara dan hara tersedia menggunakan Satuan Peta Tanah (SPT) skala 1 : 250,000 yang dikeluarkan oleh BBSDLP Kementerian Pertanian RI sebagai unit analisis. Data media perakaran diperoleh dari hasil studi pustaka sedangkan data retensi hara dan hara tersedia diperoleh dari hasil studi pustaka yang dilengkapi dengan pengujian sampel tanah. Pengujian tanah dilakukan pada 14 lokasi perkebunan teh rakyat yang mewakili 5 (lima) SPT dengan 3 (tiga) jenis tanah dominan di Kabupaten Tasikmalaya yaitu: group dystrudepts, hapludands dan hapludults. Metode pengujian tanah disajikan pada Tabel 2.

Tabel 2. Metode pengujian tanah

\begin{tabular}{ll}
\hline Sifat kimia tanah & Metode pengujian \\
\hline $\mathrm{pH}$ & $\mathrm{pH} \mathrm{H} \mathrm{H}_{2} \mathrm{O}$ \\
$\mathrm{C}$ organik & Walkley dan Black \\
$\mathrm{N}$ total & Kjeldahl \\
$\mathrm{P}_{2} \mathrm{O}_{5}$ tersedia & Bray 1 \\
$\mathrm{~K}_{2} \mathrm{O}$ dapat ditukar & Ekstraksi $\left(\mathrm{NH}_{4} \mathrm{OAc} 1 \mathrm{~N} \mathrm{pH}\right.$ \\
& $7)$ \\
Basa-basa dapat & Ekstraksi $\left(\mathrm{NH}_{4} \mathrm{OAc} 1 \mathrm{~N} \mathrm{pH}\right.$ \\
ditukar & 7) dan kejenuhan basa \\
KTK & Ekstraksi (NH $\mathrm{N}_{4} \mathrm{OAc} 1 \mathrm{~N} \mathrm{pH}$ \\
& 7) dan KTK \\
\hline
\end{tabular}

Sumber : Hikmatullah et al. (2014)

Identifikasi wilayah pengembangan perkebunan teh rakyat dilakukan melalui analisis deskriptif. Wilayah pengembangan dibagi menjadi 2 (dua) prioritas yaitu: (1) prioritas pertama (WP1) adalah wilayah pengembangan pada perkebunan teh rakyat eksisting dan (2) prioritas kedua (WP2) adalah wilayah pengembangan pada lahan yang sesuai dan tersedia untuk tanaman teh diluar perkebunan teh rakyat yang ada di Kabupaten Tasikmalaya. Penggunaan lahan berupa semak belukar dijadikan prioritas lokasi pengembangan karena diasumsikanmemiliki nilai ekonomi yang paling rendah jika dibandingkan dengan penggunaan lahan hutan, ladang/tegalan dan kebun.

Analisis kelayakan usaha tani pada penelitian ini menggunakan pendekatan penerimaan, biaya dan pendapatan usaha tani serta perhitungan nilai $R / C$ ratio (Soekartawi, 2002). Analisis kelayakan usaha tani dilengkapi dengan analisis pemasaran secara deskriptif melalui pengamatan kondisi lapangan, penggambaran dan pendeskripsian jenis-jenis rantai pemasaran (Sairdama, 2013) serta menghitung marjin pemasaran (Mayrowani \& Darwis, 2010). Jumlah responden analisis kelayakan usaha tani ditentukan menggunakan rumus Slovin (Nugraheni, 2014). Populasi yang digunakan yaitu jumlah kelompok tani teh yang teridentifikasi di Kabupaten Tasikmalaya sebanyak 119 kelompok. Tingkat kesalahan yang ditetapkan tidak lebih dari $10 \%$. Perhitungan penentuan jumlah responden adalah sebagai berikut:

$$
\begin{aligned}
& n=\frac{N}{1+N\left(e^{2}\right)} \quad \mathrm{n}=\mathrm{Jumlah} \text { responden } \\
& n=\frac{119}{1+199\left(0.1^{2}\right)} \quad \mathrm{N}=\text { Populasi } \\
& n=54.34 \approx 54 \quad \text { e=Tingkat kesalahan }
\end{aligned}
$$

Penyusunan arahan pengembangan perkebunan teh rakyat di Kabupaten Tasikmalaya menggunakan analisis Strength, Weaknesses, Opportunities, Threats (SWOT). Analisis SWOT adalah identifikasi berbagai faktor secara sistematis untuk merumuskan perencanaan strategis (Rangkuti,1997). Tahapan-tahapan yang dilakukan yaitu: pengumpulan data (faktor internal dan eksternal), analisis data dan pengambilan keputusan. Model yang digunakan yaitu: (1) matriks faktor strategi internal; (2) matriks 
faktor strategi eksternal; (3) matriks IE (internaleksternal); dan (4) matriks space.

Faktor internal dan eksternal yang berpengaruh dalam pengembangan perkebunan teh rakyat diidentifikasi berdasarkan hasil analisis pada tujuan sebelumnya dan wawancara gunamengetahui persepsi stakeholders dan penentuan bobot serta rating pada matriks faktor strategi internal dan eksternal. Responden yang diwawancarai terdiri atas petani, pengusaha, pegawai pada instansi/lembaga pemerintah dan tenaga pendidik. Penentuan bobot dilakukan dengan metode perbandingan berpasangan skala 1 sampai dengan 9. Matriks IE digunakan untuk menentukan strategi pada 9 sel strategi berdasarkan jumlah skor faktor strategi internal dan eksternal. Penajaman strategi dapat dilakukan dengan matriks space. Penajaman strategi menggunakan selisih skor untuk masing-masing faktor baik internal (kekuatan dan kelemahan) maupun eksternal (peluang dan ancaman). Analisis matriks space digunakan untuk menentukan pilihan posisi strategi yang dapat dilakukan dalam penyusunan arahan pengembangan perkebunan teh rakyat di Kabupaten Tasikmalaya.

\section{HASIL DAN PEMBAHASAN}

\section{Identifikasi sebaran lokasi perkebunan teh rakyat}

Hasil identifikasimenunjukkan bahwa perkebunan teh rakyat di Kabupaten Tasikmalaya berada di 18 kecamatan dengan luas total 9,093 ha (Dishutbun, 2015) sedangkan hasil interpretasi citra menunjukkan bahwa perkebunan teh rakyat berada di 11 kecamatan dengan luas total 6,956 ha (Tabel 3). Tingkat akurasi interpretasi citra yang diperoleh sebesar $86.30 \%$.

Tabel 3. Hasil identifikasi perkebunan teh rakyat di Kabupaten Tasikmalaya

\begin{tabular}{|c|c|c|c|c|c|}
\hline \multirow[t]{3}{*}{ Kecamatan } & \multicolumn{4}{|c|}{ Hasil penelusuran data/studi pustaka } & \multirow{3}{*}{$\begin{array}{c}\text { Hasil } \\
\text { interpretasi } \\
\text { citra (ha) }\end{array}$} \\
\hline & \multicolumn{4}{|c|}{ Kategori tanaman (ha) } & \\
\hline & TBM $^{\mathrm{a}}$ & $\mathrm{TM}^{\mathrm{b}}$ & TR/TTM $^{\mathrm{c}}$ & Jumlah & \\
\hline Bantarkalong & - & - & 5 & 5 & - \\
\hline Bojonggambir & 104 & 3,656 & 234 & 3,994 & 3,067 \\
\hline Ciawi & - & 3 & 3 & 6 & 8 \\
\hline Cigalontang & - & 96 & 63 & 159 & 166 \\
\hline Cipatujah & 4 & - & - & 4 & - \\
\hline Cisayong & - & 51 & 2.00 & 53 & 52 \\
\hline Culamega & 10 & 171 & 41 & 222 & 364 \\
\hline Kadipaten & - & 20 & 1 & 21 & - \\
\hline Karangnunggal & 2 & 26 & 5 & 33 & - \\
\hline Leuwisari & - & 12 & 165 & 177 & - \\
\hline Mangunreja & - & 6 & 7 & 13 & - \\
\hline Pagerageung & - & 117 & 96 & 213 & 55 \\
\hline Puspahiang & - & 145 & 134 & 279 & 172 \\
\hline Salawu & - & 30 & 35 & 65 & 37 \\
\hline Sariwangi & - & 47 & - & 47 & - \\
\hline Sodonghilir & 53 & 1,160 & 1,309 & 2,522 & 1,843 \\
\hline Sukahening & - & 20 & 4 & 24 & 25 \\
\hline Taraju & 75 & 963 & 217 & 1,255 & 1,167 \\
\hline Jumlah & 248 & 6,524 & 2,322 & 9,093 & 6,956 \\
\hline
\end{tabular}

Tabel 3 menunjukkanadanya perbedaan luas perkebunan teh rakyat yang teridentifikasi. Selisih luas disebabkan oleh perbedaan metode pengumpulan data. Luas perkebunan teh rakyat yang dipublikasikan Dishutbun merupakan hasil pencacahan petugas lapangan dengan pendekatan populasi tanaman per hektar (Ditjenbun, 2012). Sedangkan luas perkebunan teh hasil interpretasi ditentukan berdasarkan luas poligon hasil deliniasi. 
Perkebunan teh rakyat hasil interpretasi termasuk kategori TM dan TBM. Teh rakyat dengan kategori TR/TTM sulit teridentifikasi karena telah banyak beralih fungsi menjadi kebun campuran sehingga luas perkebunan teh yang teridentifikasi menjadi lebih kecil bila dibandingkan dengan data Dishutbun Kabupaten Tasikmalaya. Peta sebaran perkebunan teh rakyat di Kabupaten Tasikmalaya disajikan pada Gambar 1.

Perkebunan teh rakyat yang luas menjadi faktor kekuatan (strength) dalam rencana pengembangan. Selain itu, adanya perkebunan swasta yaitu PT. Sinar Inesco dan PT. Cibuniwangi berpeluang (opportunities) untuk dijadikan sebagai mitra pengembangan.

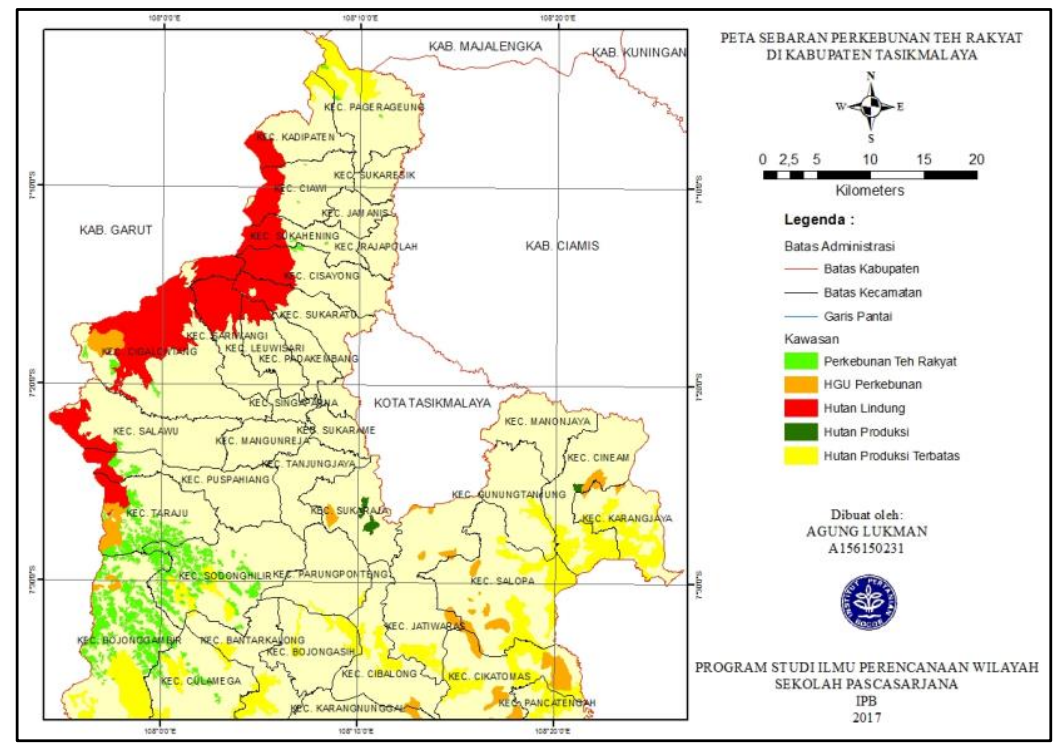

Gambar 1. Peta sebaran perkebunan teh rakyat di Kabupaten Tasikmalaya Sumber : hasil pengolahan, 2017

2. Evaluasi kesesuaian lahan dan identifikasi wilayah yang diprioritaskan untuk pengembangan perkebunan teh rakyat

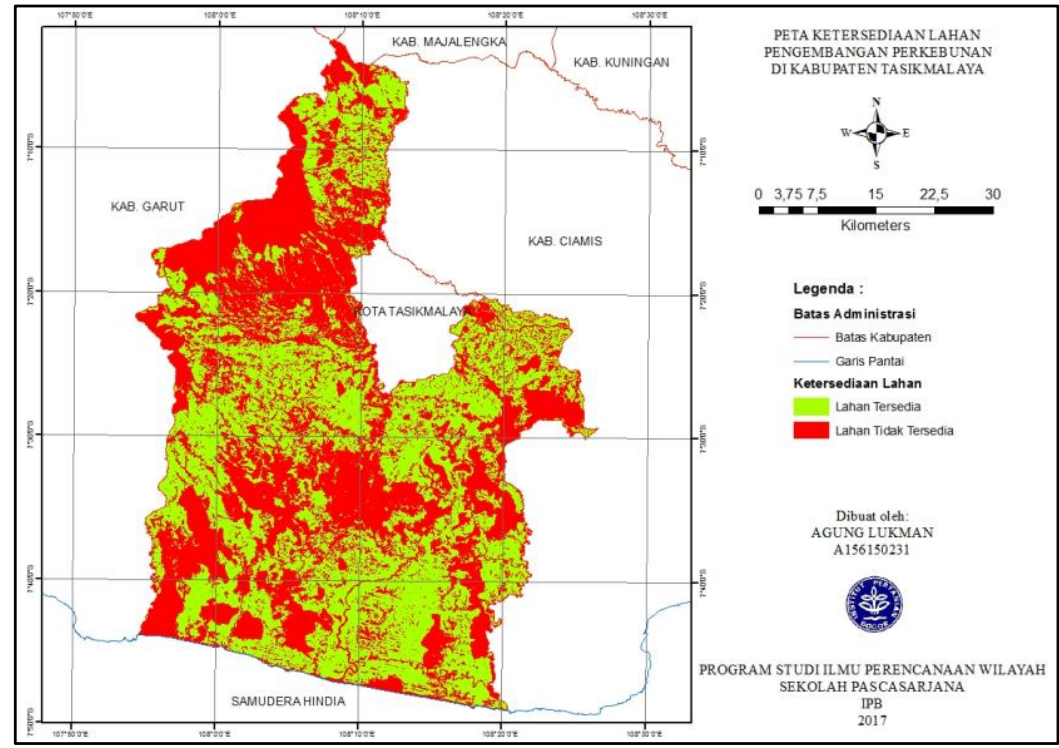

Gambar 2. Peta sebaran ketersediaan lahan untuk pengembangan perkebunan di Kabupaten Tasikmalaya

Sumber: hasil pengolahan, 2017 
Gambar 2 menunjukkan sebaran ketersediaan lahan untuk pengembangan perkebunan di Kabupaten Tasikmalaya. Lahan yang tersedia seluas 131,821 ha sedangkan yang tidak tersedia seluas 139,060 ha. Lahan yang tersedia digunakan sebagai bahan kesesuaian lahan untuk tanaman teh

Sebagian besar wilayah di Kabupaten Tasikmalaya berada pada ketinggian $0-400$ meter diatas permukaan laut (mdpl) (Tabel 4). Kondisi ini kurang menguntungkan bagi pengembangan perkebunan teh karena pada ketinggian tersebut tidak serasi untuk pertumbuhan tanaman teh (Effendi et al. 2010).

Tabel 4. Kelas kesesuaian lahan berdasarkan ketinggian

\begin{tabular}{lrc}
\hline $\begin{array}{l}\text { Kelas kesesuaian } \\
\text { lahan }\end{array}$ & Luas (ha) & $\begin{array}{c}\text { Ketinggian } \\
(\mathrm{mdpl})\end{array}$ \\
\hline S1 & 14,465 & $900-1,200$ \\
S2 & 43,406 & $600-900$ \\
& 5,212 & $1,200-1,500$ \\
S3 & 62,425 & $400-600$ \\
& 2,186 & $1,500-2,000$ \\
N & 142,985 & $0-400$ \\
\multicolumn{3}{l}{ Jumlah } \\
Sumber: Hasil pengolahan $(2017)$
\end{tabular}

Karakteristik lahan berupa ketersediaan air diduga melalui data curah hujan rata-rata per tahun. Curah hujan rata-rata berkisar antara 2,000 sampai dengan $5,500 \mathrm{~mm}$ per tahun hampir seluruh wilayah di Kabupaten Tasikmalaya sesuai untuk pertumbuhan teh karena memiliki ketersediaan air yang cukup. Kelas kesesuaian lahan berdasarkan curah hujan disajikan pada Tabel 5.

Tabel 5. Kelas kesesuaian lahan berdasarkan curah hujan

\begin{tabular}{lrc}
\hline $\begin{array}{l}\text { Kelas kesesuaian } \\
\text { lahan }\end{array}$ & Luas (ha) & $\begin{array}{l}\text { Curah hujan } \\
\text { (mm/tahun) }\end{array}$ \\
\hline S1 & 39,771 & $2,500-3,000$ \\
& 93,519 & $3,000-3,500$ \\
S2 & 101,134 & $3,500-4,000$ \\
& 311 & $2,000-2,500$ \\
& 25,002 & $4,000-4,500$ \\
S3 & 8,923 & $4,500-5,000$ \\
\hline Jumlah & 2,221 & $5,000-5,500$ \\
\hline
\end{tabular}

Sumber: Hasil pengolahan (2017)
Karakteristik lahan berupa media perakaran diduga melalui data drainase, tektur dan kedalaman efektif tanah. Drainase tanah di Kabupaten Tasikmalaya termasuk ke dalam kategori baik, sedang, agak terhambat, terhambat dan sangat terhambat dengan kedalaman efektif lebih dari $50 \mathrm{~cm}$ sedangkan tekstur tanah termasuk ke dalam kategori agak halus, sedang dan halus (Mulyono et al. 2011; Rachim dan Arifin 2013; Bappeda 2016; Bachri et al., 2016). Kelas kesesuaian lahan berdasarkan media perakaran disajikan pada Tabel 6.

Tabel 6. Kelas kesesuaian lahan berdasarkan media perakaran

\begin{tabular}{lrrr}
\hline Kelas & \multicolumn{3}{c}{ Karakteristik lahan (ha) } \\
\cline { 2 - 4 } kesesuaian & Drainase & Tekstur & $\begin{array}{c}\text { Kedalaman } \\
\text { lahan }\end{array}$ \\
\hline S1 & 140,866 & 239,652 & 171,724 \\
S2 & 104,079 & 28,835 & 12,284 \\
S3 & 23,542 & - & 84,479 \\
N & 2,394 & 2,394 & 2,394 \\
\hline Jumlah & 270,881 & 270,881 & 270,881 \\
\hline Sumber: Hasil pengolahan $(2017)$ &
\end{tabular}

Karakteristik lahan berupa bahaya erosi diduga melalui data kelerengan. Asumsi yang digunakan yaitu semakin curam kelerengan, maka tingkat bahaya erosi semakin tinggi. Kabupaten Tasikmalaya didominasi oleh kelas lereng kurang dari 8 persen (Tabel 7).

Tabel 7. Kelas kesesuaian lahan berdasarkan kelerengan

\begin{tabular}{lc}
\hline $\begin{array}{l}\text { Kelas kesesuaian } \\
\text { lahan }\end{array}$ & $\begin{array}{c}\text { Karakteristik lahan (tingkat } \\
\text { bahaya erosi) (ha) }\end{array}$ \\
\hline S1 & 190,769 \\
S2 & 66,244 \\
S3 & 13,766 \\
N & 102 \\
\hline Jumlah & 270,881 \\
\hline
\end{tabular}

Sumber: Hasil pengolahan (2017)

Karakteristik lahan berupa retensi hara diduga melalui KTK, KB, pH dan kandungan $\mathrm{C}$ Organik tanah sedangkan hara tersedia diduga melalui kandungan $\mathrm{N}$ Total, $\mathrm{P}$ tersedia dan $\mathrm{K}$ dapat ditukar dalam tanah berdasarkan SPT yang ada di Kabupaten Tasikmalaya (Tabel 8). 
Tabel 8. Data retensi hara dan hara tersedia dalam tanah di Kabupaten Tasikmalaya

\begin{tabular}{|c|c|c|c|c|c|c|c|c|}
\hline SPT & Tanah & $\begin{array}{r}\text { KTK } \\
(\mathrm{cmol})\end{array}$ & $\begin{array}{c}\text { KB } \\
(\%)\end{array}$ & pH & $\begin{array}{r}\text { C Org } \\
(\%)\end{array}$ & $\begin{array}{r}\text { N Total } \\
(\mathbf{c m o l})\end{array}$ & $\mathbf{P}(\mathbf{p p m})$ & $\begin{array}{r}\mathbf{K} \\
(\mathbf{c m o l})\end{array}$ \\
\hline 1 & Endoaquepts,Eutrudepts,Udorthents & $>16.00$ & $<20.00$ & $<3,80$ & $<0,80$ & $<0.10$ & $<10.00$ & $<0.10$ \\
\hline 2 & Endoaquepts,Eutrudepts & $>16.00$ & $<20.00$ & $<3,80$ & $<0,80$ & $<0.10$ & $<10.00$ & $<0.10$ \\
\hline 6 & Endoaquepts,Eutrudepts & $>16.00$ & $<20.00$ & $<3,80$ & $<0,80$ & $<0.10$ & $<10.00$ & $<0.10$ \\
\hline 9 & Epiaquepts,Hapludults,Dystrudepts & $>16.00$ & $<20.00$ & 7,20 & 1,76 & 0,47 & 6,00 & $<0.10$ \\
\hline 10 & Epiaquepts,Dystrudepts & $>16.00$ & $<20.00$ & 7,20 & 1,76 & 0,47 & 6,00 & $<0.10$ \\
\hline 13 & Dystrudepts,Hapludults,Epiaquepts & $>16.00$ & 16,66 & 4,21 & 0,98 & 0,30 & 6,40 & 0,13 \\
\hline 18 & Epiaquepts,Eutrudepts & $>16.00$ & $<20.00$ & 7,20 & 1,76 & 0,47 & 6,00 & $<0.10$ \\
\hline 23 & Hydraquents,Endoaquents,Udipsamments & $>16.00$ & $<20.00$ & $<3,80$ & $<0,80$ & $<0.10$ & $<10.00$ & $<0.10$ \\
\hline 33 & Endoaquents,Hydraquents,Halaquepts & $>16.00$ & $<20.00$ & $<3,80$ & $<0,80$ & $<0.10$ & $<10.00$ & $<0.10$ \\
\hline 34 & Endoaquepts,Eutrudepts,Fluvaquents & $>16.00$ & $<20.00$ & $<3,80$ & $<0,80$ & $<0.10$ & $<10.00$ & $<0.10$ \\
\hline 35 & Eutrudepts,Epiaquepts & $>16.00$ & $>50.00$ & 6,27 & $<0,80$ & 0,48 & 6,30 & $<0.10$ \\
\hline 36 & Hapludalfs,Udorthents,Eutrudepts & $>16.00$ & $>35.00$ & $>5,00$ & $<0,80$ & $0,10-0,20$ & $10.00-15.00$ & $0.10-0.30$ \\
\hline 37 & Haplustepts,Udorthents & $>16.00$ & $>50.00$ & $>5,00$ & $<0,80$ & $<0.10$ & $<10.00$ & $<0.10$ \\
\hline 38 & Hapludalft,Eutrudepts,Udorthents & $>16.00$ & $>35.00$ & $>5,00$ & $<0,80$ & $0,10-0,20$ & $10.00-15.00$ & $0.10-0.30$ \\
\hline 40 & Hapludalft,Eutrudepts,Epiaquepts & $>16.00$ & $>35.00$ & $>5,00$ & $<0,80$ & $0,10-0,20$ & $10.00-15.00$ & $0.10-0.30$ \\
\hline 42 & Hapludalfs,Eutrudepts,Udorthents & $>16.00$ & $>35.00$ & $>5,00$ & $<0,80$ & $0,10-0,20$ & $10.00-15.00$ & $0.10-0.30$ \\
\hline 43 & Hapludalfs,Eutrudepts,Udorthents & $>16.00$ & $>35.00$ & $>5,00$ & $<0,80$ & $0,10-0,20$ & $10.00-15.00$ & $0.10-0.30$ \\
\hline 44 & Hapludalfs,Eutrudepts,Udorthents & $>16.00$ & $>35.00$ & $>5,00$ & $<0,80$ & $0,10-0,20$ & $10.00-15.00$ & $0.10-0.30$ \\
\hline 55 & Hapludands,Dystrudepts,Udorthents & $>16.00$ & 34,96 & 4,49 & 0.94 & 0,18 & 5,70 & 0,19 \\
\hline 58 & Hapludands,Dystrudepts,Udorthents* & 20,40 & 34,96 & 4,49 & 0.94 & 0,18 & 5,70 & 0,19 \\
\hline 61 & Dystrudepts,Hapludults & $>16.00$ & 16,66 & 4,21 & 0,98 & 0,30 & 6,40 & 0,13 \\
\hline 62 & Dystrudepts,Hapludands, $\mathrm{U}$ & $>16.00$ & 16,66 & $<5,00$ & 0,92 & 0,26 & 6,20 & 0,38 \\
\hline 63 & Haplu & $>16.00$ & 34,96 & 4,49 & 0.94 & 0,18 & 5,70 & 0,19 \\
\hline 66 & Hapludands,Dystrudepts,Hapludults & $>16.00$ & 34,96 & 4,54 & 0.54 & 0,20 & 7,00 & 0,18 \\
\hline 72 & Hapludands,Epiaquands & $>16.00$ & 53,82 & 4,52 & 0.68 & 0,19 & 6,60 & 0,18 \\
\hline 78 & Haplud & $>16.00$ & 34,96 & 4,49 & 0.94 & 0,18 & 5,70 & 0,19 \\
\hline 83 & pts,Dystrudepts,Hapludults & $>16.00$ & 16,66 & $<5,00$ & 0,92 & 0,26 & 6,20 & 0,38 \\
\hline 84 & Hapludands,Dystrudepts,Hapludults* & 21,94 & 53,82 & 4,95 & 0,53 & 0,16 & 5,90 & 0,21 \\
\hline 89 & ts,Hapludults* & 23,74 & 40,27 & 4,12 & 0,56 & 0,23 & 8,20 & 0,14 \\
\hline 95 & Hapludands,Dys & $>16.00$ & 34,96 & 4,52 & 0.68 & 0,19 & 6,60 & 0,18 \\
\hline 98 & Dystrudepts,Epiaquepts,Ep & $>16.00$ & 32,50 & 4,58 & 0,84 & 0,21 & 5,90 & 0,63 \\
\hline 99 & Dystrudepts,Hapludults & $>16.00$ & 16,66 & 4,21 & 0,98 & 0,30 & 6,40 & 0,13 \\
\hline 102 & Dystru & 26,25 & 32,50 & 4,58 & 0,86 & 0,21 & 5,90 & 0,63 \\
\hline 105 & epts,Hapludands & $>16.00$ & 16,66 & $<5,00$ & 0,92 & 0,26 & 6,20 & 0,38 \\
\hline 106 & Dystrudepts,Udivitrands & $>16.00$ & 16,66 & $<5,00$ & 0,92 & 0,26 & 6,20 & 0,38 \\
\hline 107 & Hapluc & $>16.00$ & 20,22 & 4,52 & 1,56 & 0,26 & 4,50 & 0,32 \\
\hline 110 & Hapludults,Dystrudepts & $>16.00$ & 20,22 & 4,52 & 1,56 & 0,26 & 4,50 & 0,32 \\
\hline 111 & Epiaquepts,Dystrudepts,Hapludults & $>16.00$ & $<20.00$ & 7,20 & 1,76 & 0,47 & 6,00 & $<0.10$ \\
\hline 112 & Hapludults,Dystrudepts & $>16.00$ & 20,22 & 4,52 & 1,56 & 0,26 & 4,50 & 0,32 \\
\hline 113 & Haplu & $>16.00$ & 20,22 & 4,52 & 1,56 & 0,26 & 4,50 & 0,32 \\
\hline 116 & pts,Hapludults,Epiaquepts & $>16.00$ & 16,66 & 4,21 & 0,98 & 0,30 & 6,40 & 0,13 \\
\hline 117 & Dystrudepts,Hapludults & $>16.00$ & 16,66 & 4,21 & 0,98 & 0,30 & 6,40 & 0,13 \\
\hline 118 & Dystrudepts,Hapludults, $\mathrm{F}$ & $>16.00$ & 16,66 & 4,21 & 0,98 & 0,30 & 6,40 & 0,13 \\
\hline 119 & Paledults,Dystrudepts,Epiaquepts & $>16.00$ & $<35.00$ & 6,61 & 1,81 & 0,46 & 7,30 & $<0.10$ \\
\hline 122 & Dystrudepts,Hapludults* & 26,40 & 16,66 & 4,21 & 0,98 & 0,30 & 6,40 & 0,13 \\
\hline 123 & Dystrudepts,Hapludults, $\mathrm{H}$ & $>16.00$ & 16,66 & 4,21 & 0,98 & 0,30 & 6,40 & 0,13 \\
\hline 126 & Dystru & $>16.00$ & 16,66 & 4,21 & 0,98 & 0,30 & 6,40 & 0,13 \\
\hline 133 & Eutrudepts,Hapludults,Udorthents & $>16.00$ & $>50.00$ & 6,27 & $<0,8$ & 0,48 & 6,30 & $<0.10$ \\
\hline 134 & Hapludults,Dystrudepts,Epiaquepts & $>16.00$ & 20,22 & 4,52 & 1,56 & 0,26 & 4,50 & 0,32 \\
\hline 135 & dorthents* & 25,48 & 20,22 & 4,52 & 1,34 & 0,26 & 4,50 & 0,32 \\
\hline 136 & Hapludults,Dystrudepts,Udorthents & $>16.00$ & 20,22 & 4,52 & 1,34 & 0,26 & 4,50 & 0,32 \\
\hline 150 & Hapludults,Dystrudepts & $>16.00$ & 20,22 & 4,52 & 1,56 & 0,26 & 4,50 & 0,32 \\
\hline 153 & Hapludults,Dystrudepts & $>16.00$ & 20,22 & 4,52 & 1,56 & 0,26 & 4,50 & 0,32 \\
\hline 154 & Hapludults,Dystrudepts, $\mathrm{Ha}$ & $>16.00$ & 20,22 & 4,52 & 1,79 & 0,26 & 4,50 & 0,32 \\
\hline 155 & Hapludults,Eutrudepts,Hapludalfs & $>16.00$ & 20,22 & 4,52 & 1,56 & 0,48 & 7,00 & 0,32 \\
\hline 156 & Eutrudepts,Hapludalfs & $>16.00$ & $>50.00$ & 6,27 & $<0,80$ & 0,48 & 6,30 & $<0.10$ \\
\hline 158 & Hapludalfs,Eutrudepts & $>16.00$ & $>35.00$ & $>5,00$ & $<0,80$ & $0,10-0,20$ & $10.00-15.00$ & $0.10-0.30$ \\
\hline 999 & Badan Air/Tubuh Air & - & - & - & - & - & - & \\
\hline
\end{tabular}

Sumber: Hasil pengolahan (2017); Bappeda (2015); Mulyono et al. (2011); Rachim dan Arifin (2013); Bachri et al. (2016), diolah

Keterangan: *hasil pengujian tanah

Badan air/tubuh air yang ada pada satuan peta tanah dijadikan sebagai lahan yang tidak sesuai (N) untuk tanaman. Luas badan air yang teridentifikasi yaitu sebesar 2,394 ha. Kelas kesesuaian lahan berdasarkan retensi hara disajikan pada Tabel 9 sedangkan kelas kesesuaian lahan berdasarkan hara tersedia disajikan pada Tabel 10. 
Tabel 9. Kelas kesesuaian lahan berdasarkan retensi hara dalam tanah
Tabel 10. Kelas kesesuaian lahan berdasarkan hara tersedia dalam tanah

\begin{tabular}{|c|c|c|c|c|c|c|c|c|}
\hline \multirow{2}{*}{$\begin{array}{l}\text { Kelas } \\
\text { kesesuaian } \\
\text { lahan }\end{array}$} & \multicolumn{4}{|c|}{ Karakteristik lahan (ha) } & \multirow{2}{*}{$\begin{array}{l}\text { Kelas } \\
\text { kesesuaian } \\
\text { lahan } \\
\end{array}$} & \multicolumn{3}{|c|}{ Karakteristik lahan (ha) } \\
\hline & KTK & KB & $\mathrm{pH}$ & $\begin{array}{c}\mathrm{C} \\
\text { Organik }\end{array}$ & & $\mathrm{N}$ & $\mathrm{P}$ & K \\
\hline $\mathrm{S} 1$ & 268,487 & 95,500 & 53,261 & 190,435 & S1 & 205,349 & - & 9,964 \\
\hline $\mathrm{S} 2$ & - & 67,675 & 83,309 & 78,052 & $\mathrm{~S} 2$ & 58,961 & 32,187 & 167,236 \\
\hline S3 & - & 108,112 & 131,917 & - & S3 & 4,177 & 236,300 & 91,287 \\
\hline $\mathrm{N}$ & 2,394 & 2,394 & 2,394 & 2,394 & $\mathrm{~N}$ & 2,394 & 2,394 & 2,394 \\
\hline Jumlah & 270,881 & 270,881 & 270,881 & 270,881 & Jumlah & 270,881 & 270,881 & 270,881 \\
\hline
\end{tabular}

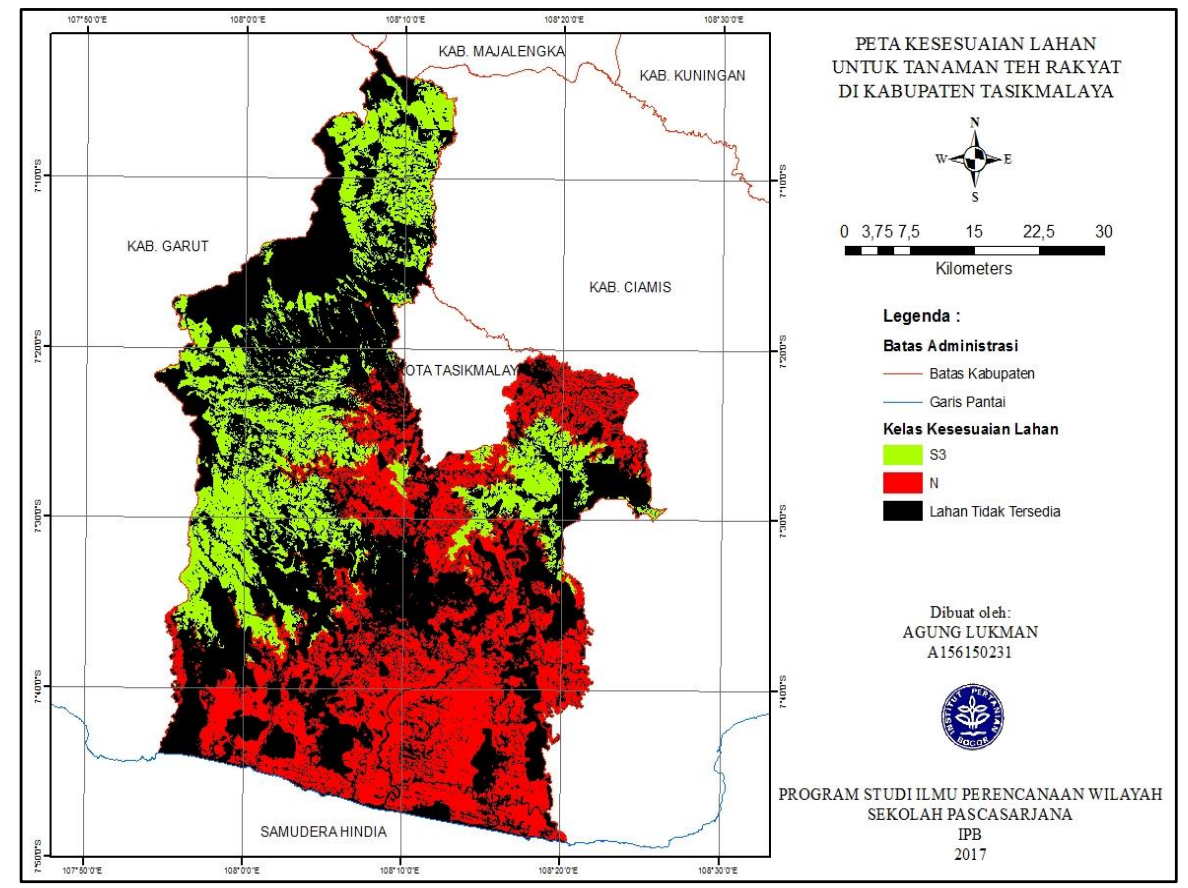

Gambar 3. Peta kesesuaian lahan untuk tanaman teh di Kabupaten Tasikmalaya Sumber: Hasil pengolahan, 2017

Lahan yang sesuai dan tersedia untuk tanaman teh di Kabupaten Tasikmalaya hanya seluas 55,310 ha dan termasuk ke dalam kelas sesuai marjinal (S3). Kelas kesesuaian S1 (sangat sesuai) dan S2 (cukup sesuai) untuk tanaman teh tidak ditemukan di Kabupaten Tasikmalaya. Selain itu, terdapat beberapa wilayah yang tidak sesuai untuk tanaman teh (N) seluas 76,511 ha. Peta sebaran kesesuaian lahan untuk tanaman teh di Kabupaten Tasikmalaya disajikan pada Gambar 3.

Faktor pembatas terbesar yang menyebabkan kelas kesesuaian lahan di Kabupaten Tasikmalaya termasuk ke dalam S3 yaitu retensi hara (f) dan hara tersedia (n)(Tabel 11).
Tabel 11. Kesesuaian lahan untuk tanaman teh berdasarkan faktor pembatasnya

\begin{tabular}{lcr}
\hline $\begin{array}{l}\text { Kelas kesesuaian } \\
\text { lahan }\end{array}$ & $\begin{array}{c}\text { Faktor } \\
\text { pembatas }\end{array}$ & Luas (ha) \\
\hline S3 & $\mathrm{f}, \mathrm{n}$ & 30,828 \\
& $\mathrm{f}, \mathrm{n}, \mathrm{e}$ & 1,793 \\
& $\mathrm{n}$ & 16,890 \\
& $\mathrm{n}, \mathrm{e}$ & 741 \\
& r,f & 930 \\
& r,f,e & 63 \\
r,f,n & 3764 \\
& r,f,n,e & 65 \\
w,f,n & 44 \\
& w,n & 191 \\
\hline
\end{tabular}

${ }^{*} \mathrm{w}=$ ketersediaan air; $\mathrm{r}=$ media perakaran; $\mathrm{f}=$ retensi hara; $\mathrm{n}=$ hara tersedia; $\mathrm{e}=$ bahaya erosi 
Perkebunan teh rakyat eksisting di Kabupaten Tasikmalaya seluas 6,952 ha termasuk ke dalam kelas kesesuaian lahan S3 sedangkan sisanya yaitu 4 ha termasuk ke dalam lahan yang tidak sesuai untuk tanaman teh. Perkebunan teh rakyat yang tidak sesuai untuk tanaman teh karena adanya faktor pembatas berupa ketinggian (h) (Tabel 12).

Tabel 12. Kesesuaian lahan untuk tanaman teh pada perkebunan rakyat eksisting berdasakan faktor pembatasnya

\begin{tabular}{llr}
\hline $\begin{array}{l}\text { Kelas kesesuaian } \\
\text { lahan }\end{array}$ & $\begin{array}{l}\text { Faktor } \\
\text { pembatas }\end{array}$ & Luas (ha) \\
\hline $\mathrm{N}$ & $\mathrm{h}$ & 4 \\
$\mathrm{~S} 3$ & $\mathrm{f}, \mathrm{n}$ & 2,470 \\
& $\mathrm{f}, \mathrm{n}, \mathrm{e}$ & 154 \\
& $\mathrm{n}$ & 4,166 \\
& $\mathrm{n}, \mathrm{e}$ & 52 \\
& $\mathrm{r}, \mathrm{f}$ & 86 \\
& r,f,e & 11 \\
& r,f,n & 14 \\
\hline
\end{tabular}

Retensi hara dan hara tersedia menjadi faktor pembatas terbesar pada perkebunan teh rakyat eksisting. Unsur hara yang terkandung dalam tanah pada wilayah tersebut cenderung sangat rendah. Oleh sebab itu, kegiatan yang dapat dilakukan pada wilayah tersebut adalah pengembangan perkebunan teh rakyat berupa kegiatan intensifikasi lahan.

Pengembangan perkebunan teh rakyat di Kabupaten Tasikmalaya dilakukan pada lahanlahan yang sesuai dan tersedia. Hasil identifikasi menunjukkan bahwa terdapat lahan seluas 55,310 ha yang dapat dijadikan sebagai wilayah pengembangan perkebunan teh rakyat namun yang diprioritaskan hanya 14,979 ha.

Lahan yang diprioritaskan untuk pengembangan perkebunan teh rakyat terdiri atas 2 (dua) kategori. Wilayah pengembangan prioritas pertama (WP1) dilakukan pada lahan perkebunan teh rakyat eksisting sedangkan prioritas kedua (WP2) adalah lahan-lahan yang sesuai dan tersedia di luar perkebunan teh yang ada dengan penggunaan lahan berupa semak belukar. Sebaran wilayah yang diprioritaskan untuk pengembangan perkebunan teh rakyat di Kabupaten Tasikmalaya disajikan pada Tabel 13 dan Gambar 4.
Tabel 13. Wilayah prioritas pengembangan perkebunan teh rakyat di Kabupaten Tasikmalaya

\begin{tabular}{|c|c|c|}
\hline Kecamatan & $\begin{array}{c}\text { Wilayah } \\
\text { pengembangan }\end{array}$ & Luas (ha) \\
\hline Bantarkalong & Prioritas 2 & 248 \\
\hline Bojongasih & Prioritas 2 & 232 \\
\hline \multirow[t]{2}{*}{ Bojonggambir } & Prioritas 1 & 2,952 \\
\hline & Prioritas 2 & 293 \\
\hline \multirow[t]{2}{*}{ Ciawi } & Prioritas 1 & 4 \\
\hline & Prioritas 2 & 583 \\
\hline Cibalong & Prioritas 2 & 1 \\
\hline \multirow{2}{*}{ Cigalontang } & Prioritas 1 & 165 \\
\hline & Prioritas 2 & 1,407 \\
\hline Cikatomas & Prioritas 2 & 14 \\
\hline Cineam & Prioritas 2 & 7 \\
\hline Cipatujah & Prioritas 2 & 48 \\
\hline \multirow[t]{2}{*}{ Cisayong } & Prioritas 1 & 52 \\
\hline & Prioritas 2 & 208 \\
\hline \multirow{2}{*}{ Culamega } & Prioritas 1 & 307 \\
\hline & Prioritas 2 & 1,151 \\
\hline Gunungtanjung & Prioritas 2 & 554 \\
\hline Jamanis & Prioritas 2 & 2 \\
\hline Jatiwaras & Prioritas 2 & 111 \\
\hline Kadipaten & Prioritas 2 & 730 \\
\hline Karangjaya & Prioritas 2 & 56 \\
\hline Leuwisari & Prioritas 2 & 263 \\
\hline Mangunreja & Prioritas 2 & 1 \\
\hline Padakembang & Prioritas 2 & 24 \\
\hline \multirow[t]{2}{*}{ Pagerageung } & Prioritas 1 & 26 \\
\hline & Prioritas 2 & 853 \\
\hline Parungponteng & Prioritas 2 & 54 \\
\hline \multirow[t]{2}{*}{ Puspahiang } & Prioritas 1 & 160 \\
\hline & Prioritas 2 & 38 \\
\hline Rajapolah & Prioritas 2 & 5 \\
\hline \multirow[t]{2}{*}{ Salawu } & Prioritas 1 & 36 \\
\hline & Prioritas 2 & 86 \\
\hline Salopa & Prioritas 2 & 727 \\
\hline Sariwangi & Prioritas 2 & 251 \\
\hline Singaparna & Prioritas 2 & 33 \\
\hline \multirow[t]{2}{*}{ Sodonghilir } & Prioritas 1 & 1,719 \\
\hline & Prioritas 2 & 18 \\
\hline \multirow[t]{2}{*}{ Sukahening } & Prioritas 1 & 25 \\
\hline & Prioritas 2 & 21 \\
\hline Sukaraja & Prioritas 2 & 10 \\
\hline Sukarame & Prioritas 2 & 7 \\
\hline Sukaratu & Prioritas 2 & 184 \\
\hline Sukaresik & Prioritas 2 & 49 \\
\hline Tanjungjaya & Prioritas 2 & 2 \\
\hline \multirow[t]{2}{*}{ Taraju } & Prioritas 1 & 1,108 \\
\hline & Prioritas 2 & 153 \\
\hline \multirow{2}{*}{ Jumlah } & Prioritas 1 & 6,554 \\
\hline & Prioritas 2 & 8,425 \\
\hline Jumlah total & & 14,979 \\
\hline
\end{tabular}

Sumber: Hasil pengolahan (2017) 
Luas wilayah pengembangan prioritas pertama (WP1) sebesar 6,554 ha atau 94.22\% dari luas perkebunan teh rakyat yang ada. Perkebunan teh rakyat seluas 378 ha tidak direkomendasikan sebagai wilayah pengembangan karena tidak sesuai dengan pola ruang. Selain itu, perkebunan teh rakyat di Kecamatan Pagerageung seluas 24 ha berada dalam kawasan hutan sehingga tidak direkomendasikan untuk dikembangkan.

Wilayah pengembangan yang dijadikan sebagai prioritas kedua yaitu seluas 8,425 ha tersebar di 35 kecamatan yang ada di Kabupaten
Tasikmalaya. Pengembangan yang dapat dilakukan yaitu kegiatan perluasan (ekstensifikasi) pada lahan-lahan semak belukar. Wilayah pengembangan terbesar berada di Kecamatan Cigalontang yaitu seluas 1,407 ha (Tabel 13).

Lahan sesuai untuk tanaman teh yang cukup luas menjadi salah satu faktor kekuatan dalam rencana pengembangan perkebunan teh. Selain itu, adanya lahan-lahan yang tersedia merupakan suatu peluang dalam pengembangan potensi wilayah untuk perkebunan teh rakyat.

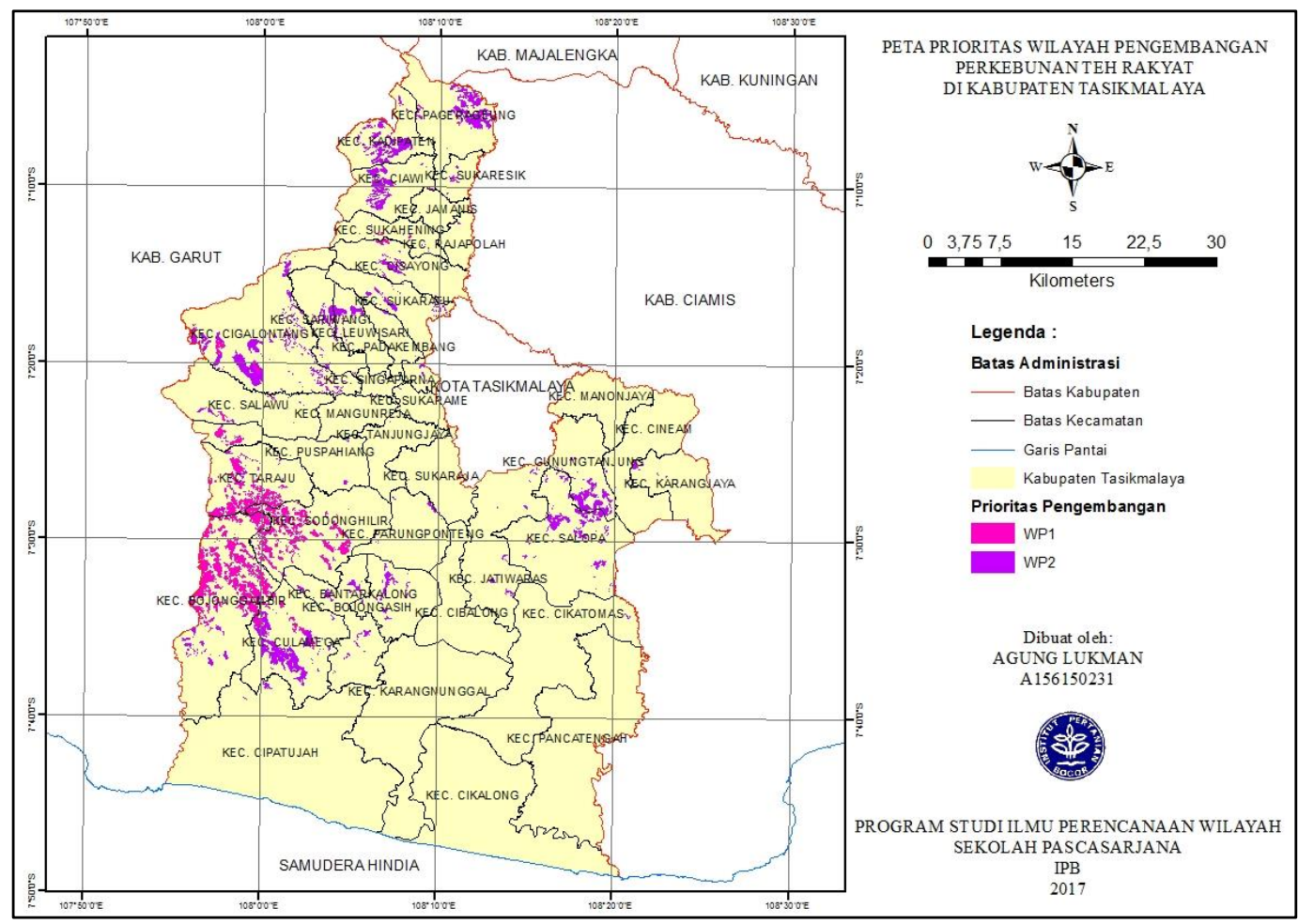

Gambar 4. Peta sebaran wilayah pengembangan perkebunan teh rakyat di Kabupaten Tasikmalaya

\section{Analisis kelayakan usaha tani teh rakyat}

Rata-rata usia responden adalah 50 tahun dengan tingkat pendidikan rata-rata SD. Jumlah tanggungan keluarga para petani teh yaitu 3 sampai dengan 4 orang. Rata-rata luas kepemilikan lahan perkebunan teh sebesar 1 ha dengan pengalaman bertani lebih dari 10 tahun.

Hasil analisis menunjukkan bahwa perkebunan teh rakyat tergolong layak dan menguntungkan untuk diusahakan berdasarkan nilai $\mathrm{R} / \mathrm{C}$ ratio yang sebesar 1.73 dalam satu tahun pengelolaan (Tabel 14). Produktivitas rata-rata petani teh pada saat penelitian dilaksanakan yaitu sebesar 7,641 kg/ha/thn daun basah. Angka tersebut masih berada dibawah standar yaitu sebesar $8,700 \mathrm{~kg} / \mathrm{ha} / \mathrm{tahun}$ daun segar (Ditjenbun, 2012, diolah). Produktivitas yang rendah disebabkan oleh kurangnya pemberian pupuk yang dilakukan oleh petani akibat keterbatasan modal. Rata-rata pupuk urea yang diberikan oleh petani sebanyak 487 $\mathrm{kg} / \mathrm{ha} / \mathrm{tahun}$ dan NPK sebanyak 208 $\mathrm{kg} / \mathrm{ha} /$ tahun. Jumlah tersebut tentunya sangat jauh berbeda dengan dosis ideal yang dianjurkan (Effendi et al., 2010 dan peraturan menteri pertanian nomor 50 Tahun 2014). Sebagai 
contoh, dosis pemupukan urea yang disarankan yaitu rata-rata sebanyak $1,050 \mathrm{~kg} / \mathrm{ha} / \mathrm{th}$.

Biaya produksi dapat mempengaruhi tingkat pendapatan petani. Biaya produksi terbesar berasal dari tenaga kerja yang mencapai $75.17 \%$ dari total biaya yang dikeluarkan. Perera (2014) menyatakan bahwa proporsi terbesar biaya produksi berasal dari tenaga kerja sedangkan Onduru et al. (2012) menyatakan bahwa biaya terbesar berasal dari tenaga kerja dan pupuk anorganik. Rata-rata pendapatan petani teh di Kabupaten Tasikmalaya yaitu Rp. $5,615,146$ per tahun atau hanya Rp. 467,929 per bulan. Selain biaya produksi, harga daun teh segar yang berfluktuatif dan cenderung rendah menjadi faktor yang mempengaruhi pendapatan.

Lembaga pemasaran teh di Kabupaten Tasikmalaya yaitu pedagang pengumpul dan juga industri pengolahan (pabrik pengeringan), namun petani cenderung menjual hasilnya ke pedagang pengumpul. Hal tersebut akibat adanya sistem ijon dalam pengelolaan perkebunan teh rakyat. Selain itu, adanya kemudahan yang didapatkan oleh petani menyebabkan kecenderungan memasarkan hasil ke pedagang pengumpul. Harga jual rata-rata daun teh basah di tingkat petani Kabupaten Tasikmalaya sebesar Rp. 1,741 per kilogram. Di Kabupaten Cianjur, harga daun teh basah bisa mencapai sebesar Rp. 2,000 per kilogram (Disbun, 2017). Harga beli di tingkat pedagang pengumpul sama dengan harga jual petani. Harga jual pedagang pengumpul sama dengan harga beli di tingkat pabrik yaitu sebesar Rp. 2,000 per kilogram. Harga jual di tingkat pabrik rata-rata sebesar Rp. 20,000 per kilogram dengan wujud produksi daun teh kering. Untuk menghasilkan 1 (satu) kilogram daun teh kering diperlukan 4 (empat) kilogram daun teh basah. Oleh sebab itu, harga jual daun teh basah di tingkat pabrik setara Rp. 5,000 per kilogram.

Marjin pemasaran di tingkat petani sebesar Rp. 3,259 per kilogram. Marjin pemasaran di tingkat pedagang pengumpul sebesar Rp. 259 per kilogram sedangkan margin di tingkat pabrik sebesar Rp. 3,000 per kilogram. Besarnya margin pemasaran di tingkat pabrik disebabkan olehadanya proses pengolahan daun teh basah menjadi daun teh kering. Biaya pengolahan yang cukup besar menyebabkan marjin pemasaran menjadi besar.

Tabel 14. Analisis kelayakan usaha tani perkebunan teh rakyat di Kabupaten Tasikmalaya

\begin{tabular}{|c|c|c|c|c|}
\hline Rincian & & Satuan & Harga & Jumlah (Rp) \\
\hline \multicolumn{5}{|l|}{ Biaya Usaha Tani } \\
\hline A. Biaya Investasi (BI) & & & & 500,000 \\
\hline - Peralatan & 1 & Set & 500,000 & 500,000 \\
\hline B. Biaya Tetap (BT) & & & & 50,000 \\
\hline - Penyusutan Peralatan & 10 & $\% /$ thn & 500,000 & 50,000 \\
\hline C. Biaya Variabel (BV) & & & & $7,135,324$ \\
\hline 1. Pupuk & & & & $1,605,325$ \\
\hline - Urea & 487 & $\mathrm{Kg} / \mathrm{ha} / \mathrm{thn}$ & 2,163 & $1,053,457$ \\
\hline - NPK & 208 & $\mathrm{Kg} / \mathrm{ha} / \mathrm{thn}$ & 2,649 & 551,868 \\
\hline 2. Pestisida & & & & 129,017 \\
\hline - Herbisida & 1.8 & Liter/ha/thn & 72,024 & 129,017 \\
\hline 3. Upah & & & & $5,400,983$ \\
\hline - Penyiangan & 35 & HOK/ha/thn & 26,000 & 897,113 \\
\hline - Pemupukan & 8 & $\mathrm{HOK} / \mathrm{ha} / \mathrm{thn}$ & 29,792 & 241,960 \\
\hline - Penyemprotan & 3 & HOK/ha/thn & 31,061 & 81,568 \\
\hline - Pemetikan & 7641 & $\mathrm{Kg} / \mathrm{ha}$ & 547 & $4,180,342$ \\
\hline Total Biaya (biaya tetap+biaya variabel) & & & & $7,185,324$ \\
\hline Modal Usaha (total biaya+biaya investasi) & & & & $7,685,324$ \\
\hline Penerimaan Usaha Tani & 7,641 & $\mathrm{Kg} / \mathrm{ha} / \mathrm{thn}$ & 1,741 & $13,300,470$ \\
\hline Pendapatan Usaha Tani & & & & $5,615,146$ \\
\hline $\mathrm{R} / \mathrm{C}$ rasio & & & & 1.73 \\
\hline
\end{tabular}

Sumber : Hasil pengolahan (2017) 


\section{Penyusunan arahan pengembangan perkebunan teh rakyat di Kabupaten Tasikmalaya}

Hasil identifikasi faktor internal dan eksternal yang berpengaruh dalam menentukan arahan pengembangan perkebunan teh rakyat disajikan pada Tabel 15. Analisis faktor strategi internal menunjukkan bahwa jumlah skor kekuatan sebesar 1.3991 dan kelemahan sebesar 1.3541 sedangkan analisis faktor strategi eksternal, jumlah skor peluang sebesar 1.3773 dan ancaman sebesar 1.2960.

Tabel 15. Hasil identifikasi dan analisis faktor strategi internal dan eksternal

\begin{tabular}{|c|c|c|c|c|c|c|c|c|}
\hline \multicolumn{2}{|c|}{$\begin{array}{l}\text { Faktor Strategi } \\
\text { Internal }\end{array}$} & Bobot & $\begin{array}{l}\text { Rat } \\
\text { ing }\end{array}$ & Skor & $\begin{array}{l}\text { Faktor Strategi } \\
\text { Eksternal }\end{array}$ & Bobot & $\begin{array}{l}\text { Rat } \\
\text { ing }\end{array}$ & Skor \\
\hline \multicolumn{5}{|c|}{ Kekuatan: } & \multicolumn{4}{|l|}{ Peluang } \\
\hline 1 & Luas areal & 0.1421 & 3 & 0.3979 & $\begin{array}{ll}1 & \begin{array}{l}\text { Teh komoditas } \\
\text { strategis }\end{array}\end{array}$ & 0.1016 & 3 & 0.3047 \\
\hline 2 & Kesesuaian lahan & 0.1933 & 4 & 0.6958 & 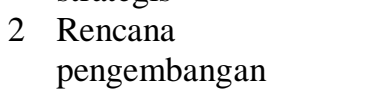 & 0.1760 & 3 & 0.5632 \\
\hline 3 & usaha tani & 0.0544 & 2 & 0.0980 & $\begin{array}{l}\text { Potensi wilayah } \\
\text { pengembangan }\end{array}$ & 0.1258 & 3 & 0.3521 \\
\hline 4 & $\begin{array}{l}\text { Kelembagaan } \\
\text { kelompok tani }\end{array}$ & 0.0646 & 2 & 0.1162 & 4 PBS sebagai mitra & 0.0419 & 1 & 0.0587 \\
\hline 5 & $\begin{array}{l}\text { Bantuan } \\
\text { pemerintah }\end{array}$ & 0.0456 & 2 & 0.0912 & $\begin{array}{l}5 \text { Rencana pembangunan } \\
\text { industri }\end{array}$ & 0.0548 & 2 & 0.0986 \\
\hline \multicolumn{5}{|c|}{ Kelemahan : } & \multicolumn{4}{|l|}{ Ancaman } \\
\hline 1 & $\begin{array}{l}\text { Posisi tawar } \\
\text { petani }\end{array}$ & 0.1094 & 3 & 0.2845 & 1 Harga yang fluktuatif & 0.1953 & 3 & 0.6639 \\
\hline 2 & $\begin{array}{l}\text { Keterbatasan } \\
\text { modal }\end{array}$ & 0.1198 & 3 & 0.3834 & 2 Konversi lahan & 0.1057 & 3 & 0.2749 \\
\hline 3 & $\begin{array}{l}\text { Produktivitas } \\
\text { rendah }\end{array}$ & 0.0697 & 3 & 0.1812 & 3 Kondisi cuaca & 0.0642 & 2 & 0.1027 \\
\hline 4 & Biaya produksi & 0.0726 & 2 & 0.1451 & 4 Rantai pemasaran & 0.0755 & 2 & 0.1360 \\
\hline 5 & Infrastruktur & 0.1285 & 3 & 0.3599 & 5 Adanya sistem ijon & 0.0593 & 2 & 0.1185 \\
\hline \multicolumn{2}{|c|}{ Jumlah } & $\mathbf{1}$ & & 2.7532 & Jumlah & & & 2.6734 \\
\hline
\end{tabular}

Sumber: Hasil analisis (2017); Novasyurahati, et al. (2014)

Pemetaan jumlah skor faktor strategi internal (2.5732) dan eksternal (2.6734) pada matriks IE (Gambar 5) menunjukkan bahwa strategi yang dapat diterapkan adalah pertumbuhan.

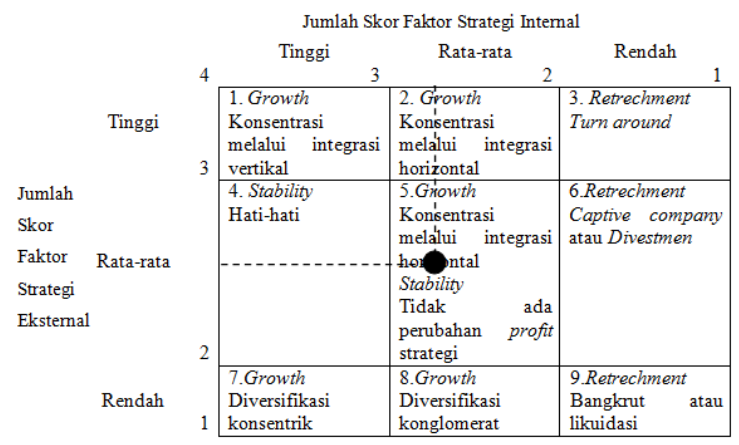

Gambar 5. Hasil analisis matriks internal - eksternal (IE)
Untuk menentukan posisi strategi dalam arahan pengembangan perkebunan teh rakyat di Kabupaten Tasikmalaya dilakukan pemetaan matriks space (Gambar 6).

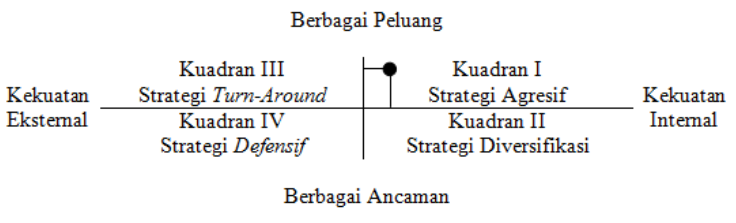

Gambar 6. Pemetaan matriks space

Hasil analisis matriks space menunjukkan bahwa pengembangan perkebunan teh rakyat di Kabupaten Tasikmalaya termasuk ke dalam strategi agresif pada kuadran I (Rangkuti, 1997). Hasil ini diperoleh dari pemetaan selisih skor faktor internal sebesar 0.0450 yang menunjukkan kekuatan internal dengan selisih 
skor faktor eksternal sebesar 0.0813 yang menunjukkan berbagai peluang yang ada.

Posisi pengembangan perkebunan teh rakyat sangat menguntungkan karena memiliki kekuatan internal dengan berbagai peluang yang dimiliki. Apabila dihubungkan dengan matriks SWOT (Tabel 16) maka dapat diketahui bahwa strategi SO diprioritaskan dalam arahan pengembangan perkebunan teh rakyat di Kabupaten Tasikmalaya sesuai dengan hasil penentuan posisi strategi pada matriks space.

Strategi SO (Kuadran I):

1. Pemerintah memfasilitasi upaya peningkatan keuntungan usaha tani teh rakyat melalui kegiatan intensifikasi lahan perkebunan teh rakyat eksisting dan pembangunan industri pengolahan. Strategi ini diterapkan pada wilayah pengembangan prioritas pertama (WP1)

2. Perluasan (ekstensifikasi) areal perkebunan teh rakyat melalui pengembangan potensi wilayah pada lahan-lahan semak belukar yang sesuai dan tersedia untuk tanaman teh. Strategi ini diterapkan pada wilayah pengembangan prioritas kedua (WP2)

3. Peningkatan peran asosiasi dan kelompok tani teh rakyat serta PBS dalam pengembangan kawasan perkebunan teh sebagai komoditas strategis di Kabupaten Tasikmalaya. Strategi ini dapat diterapkan pada kedua wilayah prioritas pengembangan mengingat kegiatan yang dilakukan berupa peningkatan peran kelembagaan pada perkebunan teh.

Tabel 16. Matriks SWOT

\begin{tabular}{|c|c|c|}
\hline Fakt & $\begin{array}{l}\text { 1. Luas areal } \\
\text { 2. Kesesuaian lahan untuk } \\
\text { tanaman teh } \\
\text { 3. Usaha tani yang } \\
\text { menguntungkan } \\
\text { 4. Adanya bantuan pemerintah } \\
\text { 5. Adanya kelembagaan } \\
\text { kelompok tani }\end{array}$ & $\begin{array}{l}\text { 1. Rendahnya posisi tawar } \\
\text { petani dalam menentukan } \\
\text { harga } \\
\text { 2. Keterbatasan modal } \\
\text { 3. Produktivitas rendah } \\
\text { 4. Tingginya biaya produksi } \\
\text { 5. Infrastruktur pendukung } \\
\text { masih kurang }\end{array}$ \\
\hline Faktor eksternal & & \\
\hline $\begin{array}{l}\text { 1. } \text { Teh merupakan komoditas } \\
\text { strategis } \\
\text { 2. Adanya potensi wilayah } \\
\text { pengembangan } \\
\text { 3. Adanya } \\
\text { pengembangan kawasan } \\
\text { perkebuna } \\
\text { 4. Adanya } \\
\text { pembangunan industri } \\
\text { 5. Adanya PBS sebagai mitra }\end{array}$ & $\begin{array}{l}\text { Strategi (SO) yaitu suatu } \\
\text { strategi yang menggunakan } \\
\text { kekuatan (Strength) dengan } \\
\text { memanfaatkan berbagai } \\
\text { peluang (Opportunities) yang } \\
\text { ada }\end{array}$ & $\begin{array}{lr}\text { Strategi (WO) yaitu strategi } \\
\text { yang } & \text { meminimalkan } \\
\text { kelemahan } & \text { (Weaknesses) } \\
\text { dengan } & \text { memanfaatkan } \\
\text { berbagai } & \text { peluang } \\
\text { (Opportunities) yang ada }\end{array}$ \\
\hline $\begin{array}{l}\text { 1. Harga yang fluktuatif } \\
\text { 2. Konversi lahan } \\
\text { 3. Kondisi cuaca tidak } \\
\text { menentu } \\
\text { 4. Rantai pemasaran yang } \\
\text { cukup panjang } \\
\text { 5. Adanya sistem ijon }\end{array}$ & $\begin{array}{l}\text { Strategi (ST) yaitu suatu } \\
\text { strategi yang menggunakan } \\
\text { kekuatan (Strength) untuk } \\
\text { mengatasi berbagai ancaman } \\
\text { (Threats) yang ada }\end{array}$ & $\begin{array}{l}\text { Strategi (WT) yaitu strategi } \\
\text { yang meminimalkan } \\
\text { kelemahan (Weaknesses) dan } \\
\text { mempertimbangkan ancaman } \\
\text { (Threats) yang ada }\end{array}$ \\
\hline
\end{tabular}

Sumber : Hasil pengolahan (2017)

\section{KESIMPULAN DAN REKOMENDASI}

Arahan pengembangan perkebunan teh rakyat di Kabupaten Tasikmalaya diprioritaskan pada usaha peningkatan keuntungan petani teh rakyat melalui intensifikasi dan rehabilitasi tanaman perkebunan teh rakyat yang telah ada seluas 6,554 ha. Perluasan areal perkebunan teh layak diusahakan pada lahan potensial yang sesuai dan tersedia seluas 8,425 ha dengan nilai 
$\mathrm{RC}$ ratio 1.73. Selain itu, pembangunan industri pengolahan diharapkan dapat meningkatkan ekonomi wilayah. Upaya tersebut perlu didukung oleh pemerintah serta berbagai pemangku kepentingan yang ada di Kabupaten Tasikmalaya.

\section{UCAPAN TERIMA KASIH}

Apresiasi dan ungkapan rasa terima kasih yang sebesar-besarnya disampaikan kepada Pusat Pembinaan, Pendidikan dan Pelatihan Perencanaan - Bappenas RI selaku pemberi sponsor kegiatan karyasiswa Tahun 2015.

\section{DAFTAR PUSTAKA}

Badan Perencanaan Pembangunan Daerah (Bappeda) Kabupaten Tasikmalaya. (2011). Rencana Tata Ruang Wilayah Kabupaten Tasikmalaya Tahun 2011 - 2031. Tasikmalaya: Bappeda Kabupaten Tasikmalaya.

Badan Perencanaan Pembangunan Daerah (Bappeda) Kabupaten Tasikmalaya. (2016). Kajian Pemanfaatan Lahan Kritis di Kabupaten Tasikmalaya. Tasikmalaya: Bappeda Kabupaten Tasikmalaya.

Dinas Kehutanan dan Perkebunan Kabupaten Tasikmalaya. (2015). Identifikasi Komoditi Perkebunan (Teh) di Kabupaten Tasikmalaya. Tasikmalaya: Dinas Kehutanan dan Perkebunan Kabupaten Tasikmalaya.

Direktorat Jenderal Perkebunan, Kementerian Pertanian. (2012). Pedoman Pelaksanaan Pengelolaan Data Komoditas Perkebunan (PDKP). Jakarta: Kementerian Pertanian.

Dinas Perkebunan Provinsi Jawa Barat. (2017). Informasi Harga Pucuk Teh. Info Harga. www.disbun.jabarprov.go.id [20 April 2017].

Efendi, D.S., Syakir, M., Yusron, M., \& Wiratno. (2010). Budidaya dan Pasca Panen Teh. Jakarta: BPPP Kementerian Pertanian.

Hardjowigeno, S. \& Widiatmaka. (2007). Evaluasi Kesesuaian Lahan dan Perencanaan Tata Guna Lahan. Yogyakarta: UGM Press.

Hikmatullah, Suparto, Tafakresnanto, C., Sukarman, Suratman, \& Nugroho K. (2014). Petunjuk Teknis Survei dan Pemetaan Tanah Tingkat Semi Detail Skala 1:50,000. Jakarta: BPPP Kementerian Pertanian.
Kementerian Pertanian. (2014). Peraturan Menteri Pertanian Nomor 50/Permentan/OT.140/4/ 2014 tentang Pedoman Teknis Budidaya Teh yang baik.

Lillesand, T. M., \& Kiefer, R. W. (1997). Penginderaan Jauh dan Interpretasi Citra. Sutanto, Ed. Yogyakarta: UGM Press.

Mayrowani, H. \& Darwis, V. (2010). Perspektif Pemasaran Bawang Merah di Kabupaten Brebes, Jawa Tengah. Di dalam : Suradisastra K., Yusdja, Y., \& Nurmanaf, A. R. Ed. Prosiding Seminar Nasional Dinamika Pembangunan Pertanian dan Perdesaan. Bogor: Pusat Analisis Sosial Ekonomi dan Kebijakan Pertanian.

Mulyono, A., Lestiana, H. \& Mulyadi, D. (2011). Kesesuaian Lahan untuk Komoditas Teh di Wilayah Sagalaherang, Subang, Jawa Barat. Jurnal Riset Geologi dan Pertambangan, 21(2), 21-36.

Novasyurahati, Sjarmidi, A., \& Gunawan, W. (2013). Strategi untuk Perbaikan Manajemen Perkebunan Teh Rakyat: Studi Kasus di Kecamatan Pasirjambu dan Ciwidey, Kabupaten Bandung. Jurnal Matematika \& Sains, 19 (2), 33-49.

Nugraheni, F. (2012). Analisis Kelayakan Usaha Tani Teh Rakyat di Desa Mojotengah Kecamatan Reban Kabupaten Batang. Skripsi. Universitas Sebelas Maret.

Onduru, D. D., de Jager, A., Hiller, S., \& Van den Bosch, R. (2012). Sustainability of smallholder tea production in developing countries: Learning experiences from farmer field schools in Kenya. International Journal of Development and Sustainability. Eng., 1(3), 714-742.

Perera, P. (2014). Tea Smallholders in Sri Lanka: Issues and Challenges in Remote Areas. International Journal of Business and Social Science. Eng., 12 (5), 107-117.

Pusat Data dan Sistem Informasi Pertanian. (2015). Statistik Perkebunan Teh Indonesia 2014 2016. Jakarta: Setjen Kementerian Pertanian.

Rachim, D. A., \& Arifin, M. (2011). Klasifikasi Tanah di Indonesia. Bandung: Pustaka Reka Cipta.

Rangkuti, F. (1997). Analisis SWOT Teknik Membedah Kasus Bisnis. Jakarta: Gramedia Pustaka Utama 
Ritung, S., Nugroho, K., Mulyani, A., \& Suryani, E. (2011). Petunjuk Teknis Evaluasi Lahan untuk Komoditas Pertanian. Bogor: BBSDLP Kementerian Pertanian.

Sairdama, S. S. (2013). Analisis Pendapatan Petani Kopi Arabika (Coffea arabica) dan Margin Pemasaran di Distrik Kamu Kabupaten Dogiyai. Jurnal Agribisnis Kepulauan, 2 (2), 44-56.

Soekartawi. (2002). Analisis Usaha Tani. Jakarta: UI Press.

Sukmono, A. (2015). Analisis Kesesuaian Lahan Teh di Banjarnegara Menggunakan Teknologi Penginderaan Jauh dan Sistem Informasi Geografis. Geoid 10, 179-186.

Wellela, N.N.K., Gunatilake, J. \& Shyamalie, H.W. (2012). Use of Geographic Information System in Tea Plantation Management: A Case Study at St, Coombs Estate, Talawakelle. J. Tea Science, Eng., 77 (1/2), 70-82. 